\title{
Improving Seed Germination of Carob and Subsequent Seedling Growth
}

\author{
Magdi Ismail Saif \\ Horticulture department, Faculty of Agriculture, Suez Canal University, 41522 Ismailia, Egypt
}

Received: $29 / 10 / 2020$

\begin{abstract}
The husk of carob seeds is very hard, therefore, its germination percentage is very low and the seeds need a long time to germinate. To get a good germination percentage of carob seeds, the seeds of carob should be scarified or treated by chemicals to improve their germination. The present study was carried out during the two successive seasons of 2019 and 2020 at the greenhouse in the experimental orchard of the Faculty of Agriculture, Suez Canal University, Ismailia, Egypt. Mechanical scarification, $\mathrm{GA}_{3}(250 \& 500 \mathrm{ppm})$, IBA $(200 \& 400 \mathrm{ppm})$, and hotbed were used to evaluate their effects on carob seed germination. Hotbed $\left(40^{\circ} \mathrm{C}\right)$ gave the most beneficial effect in improving germination percentage ( 93.3 and $100 \%$, respectively in the two seasons, compared to control (16.7 and 25\%) followed by $\mathrm{GA}_{3}$ then IBA treatments and increased germination index 6-7 fold of control. Not only that, but hotbed treatment improved the growth of carob seedlings.
\end{abstract}

Keywords: Carob, (Ceratonia siliqua L.), Scarification, $\mathrm{GA}_{3}$, IBA, Hotbed Germination

\section{INTRODUCTION}

Carob (Ceratonia siliqua L.), is widely cultivated in the Mediterranean area especially the region from the southern coast of Asia Minor to Morocco, and its cultivation in marginal and prevailing calcareous soils of the Mediterranean region is important environmentally and economically (Konate et al., 2007). Carob is an important source of natural nutraceuticals and antioxidants. For its role in functional food, in the future, there will be needs to use it not only as a food but also in pharmaceutical industries and medicine (Petkova et al., 2017; Goulas and Georgiou, 2019). Moreover, the possibility of using tree carbon sequestration as an ecosystem service (Correia and Pestana, 2018). The average carob fruits price is about $\$ 844$ per tonne. The global carob market revenue amounted to 111 billion $\$$ in 2018 cultivated in 42867 ha which produced 144961 tonnes with very variable yields depending on cultivar, region, and farming practice. Portugal is the first carob producer with an average of 41734 tonnes then followed by other Mediterranean countries (FAO, 2020).

In Egypt, carob trees are cultivated in limited acreage, which encounters some defects for propagation with seeds. According to Kozlowski and Pallardy (1997) and Baskin and Baskin (2014), the seeds of legumes frequently associated with seed coat characteristics, which are due to the hard absorbance of the coat to water and gases. Shepperd (2008) exhibited that the husk of carob seeds is very hard, therefore, its germination percentage is very low and the seeds need a long time to germinate. Rhizopoulou and Davies (1991) conducted that legumes dry seeds, become hard and not easily absorb water after sowing. Therefore, many investigators have used different treatments to accelerate and increase seed germination and subsequent seedlings growth for carob. From the investigators who used mechanical scarification to improve carob husk to absorb water and enhance the germination percentage (Coit, 1951 and Lamlom and Abdalrasol 2016). Bano et al. (2019) treated Inula racemosa with $\mathrm{GA}_{3}$, induced a significant decrease of the germination period by one month. Due to the hot treatments, Kozlowski and Pallardy (1997) reported that heat can break dormancy for seeds that have a hard seed coat. In addition to that, the hard seeds of leguminous plants sometimes required heat 55 to $60^{\circ} \mathrm{C}$ to break the dormancy of its seeds. In respect to carob seed germination by hotbed, no available data on this subject was found in the literature.

Thus, the objective of this study is to find the best treatment(s) to improve germination parameters of carob seeds and their subsequent seedling growth.

\section{MATERIALS AND METHODS}

The present study was carried out during the two successive seasons of 2019 and 2020 at the greenhouse in the experimental orchard of the Faculty of Agriculture, Suez Canal University, Ismailia, Egypt.

Dry ripe bods of carob were picked from trees growing at the faculty of Agriculture, Suez Canal University. Mature and sound seeds were collected from bods and selected the sound and homogeneous seeds then divided into seven treatments as following:

1- Control: Seeds were soaked in tap water for 3 hours before sown.

2- Scarification: Seeds were scarified from the far part of their embryo using a rough surface (sandpaper) before sowing.

3- $\mathbf{G A}_{\mathbf{3}} \mathbf{2 5 0}$ : Seeds were dipped in $250 \mathrm{ppm}$ of $\mathrm{GA}_{3}$ for 3 hours before sown.

4- $\mathbf{G A}_{3} \mathbf{5 0 0}$ : Seeds were dipped in $500 \mathrm{ppm}$ of $\mathrm{GA}_{3}$ for 3 hours before sown.

5- IBA 200: Seeds were dipped in $200 \mathrm{ppm}$ of IBA for 3 hours before sown.

6- IBA 400: Seeds were dipped in $400 \mathrm{ppm}$ of IBA for 3 hours before sown.

7- Hotbed: Seeds were soaked in tap water for 3 hours (as control) but its planting container was placed on a hot plate $40 \pm 2^{\circ} \mathrm{C}$ for 1 month.

Carob seeds were used with three replicates in every treatment ( 20 seeds at each replicate) and sowed in square black plastic pots $(7 \times 7 \times 15 \mathrm{~cm})$ in wet mixed media (1 peat moss : 1 perlite : 1 clean sand). Seeds sowed in the first week of January for the two seasons. 
All treatments were regularly watered and subjected to the same agricultural practices. After the emergence of the first seedling, the number of germinated seeds was counted every 3 to 4 days intervals until seed germination ceased.

Germination data were recorded and calculated from it the germination parameters according to Kader (2005), Ranal and Santana (2006) and Al-Ansari and Ksiksi (2016), which include:

Germination percentage after 30 days from sowing (G30P) and Germination percentage after 60 days from sowing (G60P).

Mean Germination Time $($ MGT) $=\mathbf{P f} \cdot \mathbf{x} / \mathbf{P f}$

Where $\mathrm{f}=$ Seeds germinated on day $\mathrm{x}$

Final germination percentage (FGP): Final no. of seeds germinated in a seed lot $\times 100=$ (Number of emerged seedlings/Total number of seeds $) \times 100$

Germination index (GRI) $=\mathrm{N} 1 / \mathrm{D} 1+\mathrm{N} 2 / \mathrm{D} 2+$ $\mathrm{N} 3 / \mathrm{D} 3+------+\mathrm{N}_{\mathrm{n}} / \mathrm{D}_{\mathrm{n}}$

Where, $\mathrm{N}=$ Number of emerged seedlings per day, $\mathrm{D}=$ Number of days from the start of the count

The number of leaves, number of leaflets, number of roots, and root length $(\mathrm{cm})$ were measured in the last week of March.

\section{Statistical analysis}

Statistical analysis was performed using CoStat 6.400 software. The experiment was designated in a completely randomized design, and the data were analyzed by one-way analysis of variance (ANOVA). Multiple comparisons among the mean values were performed with LSD and Duncan's Multiple Range Test (alpha 5\% level of significance).

\section{RESULTS AND DISCUSSION}

Carob seeds germinated after 3 weeks in the $7^{\text {th }}$ treatment (hotbed) and after 4 weeks in other treatments. Results in Table (1), indicated that the germination percentage stabled after the $2^{\text {nd }}$ week of March and the maximum seeds germination percentage was in the first week of February for the two seasons.

Scarification of seeds, not significantly affected germination after 30 day percentage (G30P) of carob seeds while significantly increased germination after 60 day percentage (G60P) by about 5 to $6.7 \%$ and final germination percentage (FGP) by 1.5 fold in the first season and by 1.2 fold in the second one compared to control (Table 1). This treatment showed a significant increase in germination index (GRI) and achieved 1.5 to 2 fold respectively compared to control in the two seasons. The scarification treatment improved morphological measurements of carob seedlings as shown in Table (2). These findings were in agreement with that reported by Toogood (2019) who discussed that seeds dormancy is usually happened by a hard seed coat, chemical inhibition of the embryo, or an immature embryo. Additionally, Physical seed surface scarification by sandpaper allows water to reach the seed embryo. In a study by Salazar and Sandoval (2019) on mechanically scarified Schizolobium parahyba seeds, they got a result of $92.5 \pm 2.5 \%$ germination. Due to their observation, coats of $S$. parahyba seeds that soaked in water did not absorb water but mechanically scarified seeds absorbed it because of scarification that improved the coats of seeds to imbibe water. This was in accordance with Kruger et al. (2018) who proved that the final germination percentage (FGP) achieved $90 \%$ in the treatment of carob mechanical scarification.

$\mathrm{GA}_{3}$, treatments significantly increased carob seeds G30P by 5 times and G60P by three times in the $1^{\text {st }}$ season and two times in the second one compared to control. Moreover, this treatment significantly increased FGP to be 48.3 and $53.3 \%$ compared to the control (16.7 and 25\%) and significantly increased the germination index to record more than two times of control (Table 1). GA 3 plays a role in the induction of $\alpha$ amylase and protease in the seeds, hence facilitating endosperm mobilization and promotion of seed germination (Edwin et al., 2008). The role of $\mathrm{GA}_{3}$ and auxins in plants is explained by Davies (2010), who concluded that $\mathrm{GA}_{3}$ control hydrolase gene expression while, auxin resulted in wall loosening. The growth of seedlings also affected by $\mathrm{GA}_{3}$ treatments which increased the number of leaves and leaflets and also root length 1.5 to 2 times compared to control except the number of roots (Table 2) without significant difference between $\mathrm{GA}_{3} 200$ and $400 \mathrm{ppm}$ treatments. The obtained results are in harmony with those germination index reported by Edwin et al. (2008) who concluded that Gibberellins in addition to their role in promoting elongation in stems and leaves by activation of the intercalary meristem.

In the current study, IBA significantly increased G30P and G60P by 2 and 1.5 times, respectively compared to the control treatment. The germination percentage varied from 26.7 to $33 \%$ with IBA treatments compared to 16.7 and $25 \%$ in control treatment but the germination index showed a significant increase compared to control (Table 1). The IBA treatment significantly increased the number of leaves, number of leaflets but did not affect the number of roots compared to control in the two seasons. The root length significantly increased and recorded 3.6 to $3.9 \mathrm{~cm}$ with IBA compared to 1.7 and $1.8 \mathrm{~cm}$ in control (Table 2) without significant difference between IBA 200 and 400 ppm. Van der Krieken et al. (1992) demonstrated the effect of IBA in combination with cytokinins, as their role to enhance the growth of cells, and tissues. Moreover, Aloni (2010) confirmed that auxins stimulate the differentiation of buds and roots.

The highest G30P was detected in treatment No. 7 (hotbed) which recorded 51.7 and 60\% respectively in the two seasons compared to control. In addition to that, the final germination percentage recorded 93.3 to $100 \%$ compared to 16.7 to $23.3 \%$ in control. The hotbed treatment significantly increased FGP to $93.3 \%$ in the first season and $100 \%$ in the second season. Also, GRI had the highest significance in the current treatment compared to all other treatments and recorded 0.601 and 0.666 which mean 6 fold of control (Table 1).

Results of the current investigation, in general, showed that the hotbed treatment had the maximum beneficial effect in improving the germination 
percentage of carob seeds followed by $\mathrm{GA}_{3}$ treatments then IBA and scarification treatments but the lowest treatment was control. Not only that but also the hotbed treatment significantly increased GRI compared to other treatments in the two seasons of the experiment followed by $\mathrm{GA}_{3}$ treatments then IBA treatments. The results of hotbed treatment and its effect on germination can be discussed according to Baskin and Baskin (2014) who reported that high temperature through the germination process can lead to improvement of seed germination by break physical dormancy for seeds which have hard husk. Also, Kozlowski and Pallardy (1997) reported that some seeds leguminous plants sometimes required heat of more than $50^{\circ} \mathrm{C}$ to break its seeds dormancy.
With regard to the effects of different treatments on morphological measurements of carob seedlings, leaves and leaflets numbers were significantly increased by hotbed treatment of seeds. In addition, the significantly highest root length $(4.8$ and $4.7 \mathrm{~cm})$ was obtained with the hotbed treatment compared to untreated seeds (control) which recorded the lowest length $(1.7$ and $1.8 \mathrm{~cm})$ as shown in Table 2. Hotbed treatment resulted in the highest percentages not only in germination parameters but also in seedlings growth parameters followed by $\mathrm{GA}_{3}$, IBA, and scarification treatments compared to control (Table 2). The maximum roots number and length at the hotbed treatments were detected. These results can be discussed by Shry and Reiley (2017) who reported that when the temperature rises, more nutrients are released.

Table (1): Effect of scarification, IBA, $\mathrm{GA}_{3}$ and hotbed on germination parameters of carob seeds in 2019 and 2020 seasons

\begin{tabular}{|c|c|c|c|c|c|c|c|c|}
\hline \multirow{2}{*}{ Treatment } & \multicolumn{2}{|c|}{${ }^{*} \mathrm{G} 30 \mathrm{P}$} & \multicolumn{2}{|c|}{ G60P } & \multicolumn{2}{|c|}{ FGP } & \multicolumn{2}{|c|}{ GRI } \\
\hline & 2019 & 2020 & 2019 & 2020 & 2019 & 2020 & 2019 & 2020 \\
\hline Control & $06.7 \mathrm{e}$ & $08.3 \mathrm{~d}$ & $16.7 \mathrm{~d}$ & $23.3 \mathrm{~d}$ & $16.7 \mathrm{~d}$ & $25.0 \mathrm{~d}$ & $0.086 \mathrm{~d}$ & $0.123 \mathrm{c}$ \\
\hline Scarification & $10.0 \mathrm{de}$ & $11.7 \mathrm{~cd}$ & $21.7 \mathrm{c}$ & $30.0 \mathrm{c}$ & $25.0 \mathrm{c}$ & $30.0 \mathrm{c}$ & $0.129 \mathrm{c}$ & $0.158 \mathrm{c}$ \\
\hline $\mathbf{G A}_{3} 250$ & $43.3 \mathrm{~b}$ & $36.7 \mathrm{~b}$ & $53.3 \mathrm{~b}$ & $48.3 \mathrm{~b}$ & $53.3 \mathrm{~b}$ & $50.0 \mathrm{~b}$ & $0.320 \mathrm{~b}$ & $0.293 \mathrm{~b}$ \\
\hline $\mathbf{G A}_{3} \mathbf{5 0 0}$ & $36.7 \mathrm{c}$ & $36.7 \mathrm{~b}$ & $50.0 \mathrm{~b}$ & $48.3 \mathrm{~b}$ & $53.3 \mathrm{~b}$ & $48.3 \mathrm{~b}$ & $0.296 \mathrm{~b}$ & $0.285 \mathrm{~b}$ \\
\hline IBA 200 & $13.3 \mathrm{~d}$ & $16.7 \mathrm{c}$ & $23.3 \mathrm{c}$ & $31.7 \mathrm{c}$ & $26.7 \mathrm{c}$ & $31.7 \mathrm{c}$ & $0.143 \mathrm{c}$ & $0.172 \mathrm{c}$ \\
\hline IBA 400 & $13.3 \mathrm{~d}$ & $15.0 \mathrm{c}$ & $25.0 \mathrm{c}$ & $31.7 \mathrm{c}$ & $26.7 \mathrm{c}$ & $33.3 \mathrm{c}$ & 0.143 & $0.171 \mathrm{c}$ \\
\hline Hotbed & $51.7 \mathrm{a}$ & $60.0 \mathrm{a}$ & $93.3 \mathrm{a}$ & $100 \mathrm{a}$ & $93.3 \mathrm{a}$ & $100 \mathrm{a}$ & $0.601 \mathrm{a}$ & 0.666 a \\
\hline LSD** & 4.7 & 4.3 & 4.3 & 4.3 & 4.68 & 3.31 & 0.028 & 0.023 \\
\hline $\begin{array}{l}\text { * G30P: Germ } \\
\text { G60P: Germ }\end{array}$ & $\begin{array}{l}\text { n percentas } \\
\text { n percentas }\end{array}$ & $\begin{array}{l}\text { ter } 30 \text { days } \\
\text { ter } 60 \text { days }\end{array}$ & $\begin{array}{l}\mathrm{n} \text { sowing } \\
\mathrm{n} \text { sowing }\end{array}$ & & $\begin{array}{l}\text { FGP: } 1 \\
\text { GRI: }\end{array}$ & $\begin{array}{l}\text { l germin } \\
\text { mination }\end{array}$ & percentage & \\
\hline
\end{tabular}

Table (2): Effect of scarification, IBA, $\mathrm{GA}_{3}$ and hotbed on morphological measurements of carob seedlings in 2019 and 2020 seasons

\begin{tabular}{|c|c|c|c|c|c|c|c|c|}
\hline \multirow{2}{*}{ Treatment } & \multicolumn{2}{|c|}{ No. of leaves } & \multicolumn{2}{|c|}{ No. of leaflets } & \multicolumn{2}{|c|}{ No. of roots } & \multicolumn{2}{|c|}{ Root length (cm) } \\
\hline & 2019 & 2020 & 2019 & 2020 & 2019 & 2020 & 2019 & 2020 \\
\hline Control & $1.7 \mathrm{c}$ & $2.0 \mathrm{c}$ & $3.3 \mathrm{c}$ & $4.0 \mathrm{c}$ & $3.0 \mathrm{c}$ & $3.0 \mathrm{c}$ & $1.7 \mathrm{~d}$ & $1.8 \mathrm{~d}$ \\
\hline Scarification & $3.3 \mathrm{ab}$ & $3.3 \mathrm{~b}$ & $6.7 \mathrm{ab}$ & $6.7 \mathrm{~b}$ & $5.3 \mathrm{a}$ & $4.7 \mathrm{~b}$ & $2.3 \mathrm{c}$ & $1.9 \mathrm{~d}$ \\
\hline $\mathrm{GA}_{3} 250$ & $3.0 \mathrm{ab}$ & $3.3 \mathrm{~b}$ & $6.0 \mathrm{ab}$ & $6.7 \mathrm{~b}$ & $4.3 \mathrm{~b}$ & $4.3 \mathrm{~b}$ & $3.7 \mathrm{~b}$ & 3.6 \\
\hline $\mathbf{G A}_{3} \mathbf{5 0 0}$ & $3.0 \mathrm{ab}$ & $3.0 \mathrm{~b}$ & $5.3 \mathrm{bc}$ & $6.7 \mathrm{~b}$ & $4.0 \mathrm{~b}$ & $4.0 \mathrm{~b}$ & $3.8 \mathrm{~b}$ & $3.8 \mathrm{~b}$ \\
\hline IBA 200 & $2.3 \mathrm{bc}$ & $3.0 \mathrm{~b}$ & $4.7 \mathrm{bc}$ & $6.0 \mathrm{~b}$ & $3.0 \mathrm{c}$ & $3.0 \mathrm{c}$ & $3.8 \mathrm{~b}$ & $3.8 \mathrm{~b}$ \\
\hline IBA 400 & $2.7 \mathrm{~b}$ & $3.0 \mathrm{~b}$ & $5.3 \mathrm{bc}$ & $6.0 \mathrm{~b}$ & $3.0 \mathrm{c}$ & $3.0 \mathrm{c}$ & $3.6 \mathrm{~b}$ & $3.9 \mathrm{~b}$ \\
\hline Hotbed & $4.0 \mathrm{a}$ & $4.0 \mathrm{a}$ & $8.0 \mathrm{a}$ & $9.3 \mathrm{a}$ & $5.3 \mathrm{a}$ & $5.7 \quad \mathrm{a}$ & $4.8 \mathrm{a}$ & $4.7 \mathrm{a}$ \\
\hline LSD* & 0.76 & 0.54 & 1.71 & 1.53 & 0.66 & 0.66 & 0.35 & 0.21 \\
\hline
\end{tabular}

*Means in the same column with the same letters are not significantly different at $p<0.05$ according to Duncan's multiple range tests

\section{CONCLUSION}

The present work showed that all treatments clearly improved the germination parameters and morphological measurements of carob seedlings individually. However, comparing the different studied treatments, sowing carob seeds at hotbed had the most beneficial effect in improving its germination and so the growth of carob seedlings followed by $\mathrm{GA}_{3}$ then IBA and scarification treatments. So the hotbed treatment represents the best efficacious treatment option for increasing the germination of carob seeds. 


\section{REFERENCES}

Al-Ansari, F. and T. Ksiksi (2016). A Quantitative Assessment of Germination Parameters: the Case of Crotalaria persica and Tephrosia apollinea. The Open Ecology Journal, 9: 1321.

Aloni, R. (2010). The induction of vascular tissues by auxin. In Davies P. J. ( $3^{\text {rd }}$ edition) Plant Hormones, Springer, Dordrecht, 485-518 pp.

Bano, H., J. Bhat, F. A. Lone, F. Noor, M. Bhat and N. Nazir (2019). Effect of Phytohormones and Other Dormancy Breaking Chemicals on Seed Germination of Inula racemosa Hook F. - A Critically Endangered Medicinal Plant of North Western Himalaya. Int. J. Curr. Microbiol. App. Sci., 8(3): 866-876.

Baskin, C. C. and J. M. Baskin (2014). Seeds. Ecology, biogeography, and evolution of dormancy and germination. $2^{\text {nd }}$ ed. London: Academic Press, $1600 \mathrm{pp}$.

Coit, J. E. (1951). Carob or St. Johnsbread. Journal of Economic Botany, 5(1): 82-96.

Correia, P. J. and M. Pestana. (2018). Exploratory Analysis of the Productivity of Carob Tree (Ceratonia siliqua) Orchards Conducted under Dry-Farming Conditions. Sustainability, 10(7): 1-7.

Davies, P. J. (2010). Plant Hormones ( $3^{\text {rd }}$ edition), Springer, Dordrecht, $835 \mathrm{pp}$.

Edwin F. G., A. H. Michael and D. K. Geert-Jan (2008). Plant Propagation by Tissue Culture ( $3^{\text {rd }}$ Edition), Springer, P.O. Box 17, 3300 AA Dordrecht, the Netherlands, $501 \mathrm{pp}$.

FAO (2020). FAO-Statistical Data. Available at: www.fao.org

Goulas, V. and E. Georgiou (2019). Utilization of Carob Fruit as Sources of Phenolic Compounds with Antioxidant Potential: Extraction Optimization and Application in Food Models. Foods, 9(1): 20.

Kader, M. A. (2005). A comparison of seed germination calculation formulae and the associated interpretation of resulting data. Journal \& Proceedings of the Royal Society of New South Wales, 138: 65-75.

Konate, I., A. F. Maltouf and El. B. Berraho (2007). Diversity Analysis of Moroccan Carob (Ceratonia siliqua L.). Acta Botanica Malacitana Málaga, 32: 79-90.
Kozlowski, T. T. and S. G. Pallardy (1997) Growth Control in Woody Plants. Academic Press Inc., 525 B Street, San Diego, Ca 92101-4495, $642 \mathrm{pp}$.

Kruger, F. J. L., H. T. Araya, R. Kleynhans and C. P. du Plooy (2018). Enhancing seed germination of Ceratonia siliqua L. for large scale production in southern Africa. Acta Hortic., 1204: 139-142.

Lamlom, S. H. and E. M. Abdalrasol (2016). Effects of various pre-sowing treatments on seed germination of Carob (Ceratonia siliqua L.) from Al-Akhdar Area (Balagrae, Al-Baida, Lybia). J. Agric. Vet. Sci., 9(9): 16-24.

Petkova, N., I. Petrova, I. Ivanov, R. Mihov, R. Hadjikinova, M. Ognyanov and V. Nikolova (2017). Nutritional and antioxidant potential of carob (Ceratonia siliqua) flour and evaluation of functional properties of its polysaccharide fraction. J. Pharm. Sci. \& Res., 9: 2189-2195.

Ranal M. and D. Santana (2006). How and why to measure the germination process. Brazilian Journal of Botany, 29: 1-11.

Rhizopoulou, S. and W. J. Davies (1991). Influence of soil drying on root development, water relations and leaf growth of Ceratonia siliqua L. Oecologia, 88(1): 41-47.

Salazar, A. and S. R. Sandoval (2019). Effects of mechanical and acid scarification on germination performance of Schizolobium parahyba (Fabaceae - Caesalpinioideae) seeds. Journal of Tropical Biology and Conservation, 16: 213-227.

Shepperd, W. D. (2008). Ceratonia siliqua L.: Fabaceae - Pea Family Ceratonia siliqua L. Carob, USDA FS Agriculture Handbook 727The Woody Plant Seed Manual, pp. 371-373.

Shry C. L. and A. E. Reiley (2017). Introductory Horticulture $9^{\text {th }}$ Edition. Copyright 2017 Cengage Learning. Delmar 5 Maxwell Drive Clifton Park, NY 12065-2919, USA, 960 pp.

Toogood, A. (2019). RHS Propagating Plants: How to Create New Plants for Free. DK Publishing (Dorling Kindersley), 320 pp.

Van Der Krieken, W. M., H. Breteler and M. H. M. Visser (1992). Uptake and metabolism of indolebutyric acid during root formation on Malus microcuttings. Acta Bot. Neerl., 41: 435-442.

\section{زيادة إنبات بذور الخروب وتحسين نمو شتنلاته \\ مجدي إسماعيل عبد العزيز سيف

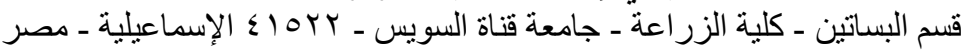

تتميز بذور الخروب بقترة صلبة تعيق وتؤخر وتقلل إنباتها لذلك تحتاج البذور لبعض المعاملات قبل زر اعتها اعتها حتى يمكن تحسين

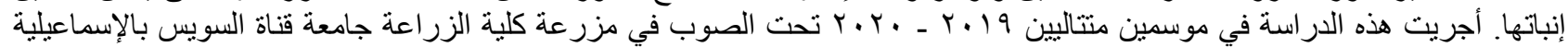

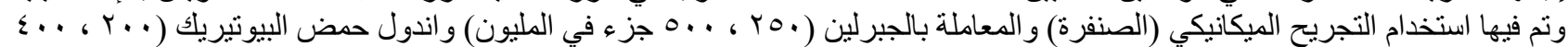

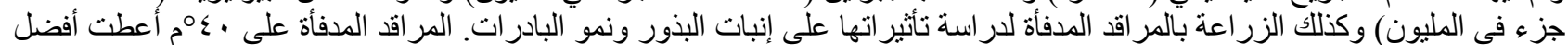

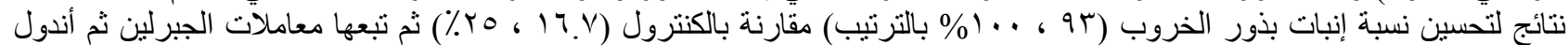

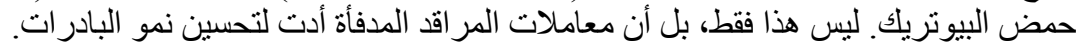

